\title{
Influence of Geometry of Twisted Tape Insert on Heat Transfer Augmentation
}

\author{
S. Sam Godwin Sathyaraj, M. Sivasubramanian, K.D Jaganathan.
}

\begin{abstract}
Heat exchangers are commonly used devices in several industrial applications owing to their high performance in transferring the heat from the hot nature to cold nature. Heat exchangers are necessary for saving energy, there are lots of methods implied to increase the thermal performance of heat transfer device by changing the surface of the flow area of the fluids.in most of the methods there is an insertion in the flow passage like twisted tape or blocks to make a disturb in the flow. Mainly these twisted tapes have a vital role in the heat transfer characters. In this present paper the various techniques used in increasing the heat transfer with the insertion of twisted tape and its geometrical influences on the performance of heat transfer were studied and reported.
\end{abstract}

Keywords : Heat transfer augmentation, Twisted Tape inserts, Swirl flow, Reynolds number heat transfer enhancement, Twist ratio.

\section{INTRODUCTION}

$\mathrm{H}_{\mathrm{s}}$ eat transfer enhancement is used varied by the uses of the heat exchangers in the various industrial applications. These heat exchangers are classified into two methods based the technique used in the exchangers. Basically these methods are considered by the characteristic of the exchangers and the flow path augmentation has been seen by various types of the tapes. These tapes are varied in types rectangular cut, square cut, with or without oblique teeth and the flow path in the heat exchangers are varied by rough surface and swirl flow. In here these methods are useful for the cost effective methods in the low range of cost will give the maximum efficiency in the heat transfer coefficient. These will generate flow in the swirl manner will get a high friction as it will flow through the maximum surface area. Instead these methods the heat transfer is maximized by the external source like mechanical aids and surface flow vibrations and electrostatic field uses.

Tubular heats exchangers are used in the chemical process industries because of its low coefficient of heat transfer, the flow over the tube have a laminar flow which had a high flow rate of hot fluid. This present study reviews the role of the geometrical changes in the insertion of the twisted

Revised Manuscript Received on December 5, 2019

* M Sivasubramanian

Sam Godwin Sathyaraj, Research Scholar, Department of Automobile Engineering, School of Automotive and Mechanical Engineering, Kalasalingam Academy of Research and Education, Tamilnadu - India. Email:samgodwin92@gmail.com

K.D.Jaganathan, Assistant Professor, Department of Mechanical Engineering, SACS MAVMM Engineering college, Madurai, Tamil Nadu, India. Email: jaganathan1978@gmail.com

M Sivasubramanian*, Department of Automobile Engineering, School of Automotive and Mechanical Engineering, Kalasalingam Academy of Research and Education, Tamilnadu - India. Email: m.sivasubramanian@klu.ac.in tape on intensification of heat transfer. The geometrical changes include the aspect ratio of the twisted tape, perforations, external cuts and modifications in its surface.

\section{LITERATURE REVIEW}

Double pipe heat exchangers with concentric nature has a twisted tape insert with various twist ratio has been discussed by Watcharin et al [1] It is reported that Nusselt number had increased about $188 \%$ and $159 \%$ respectively .The medium used for heat transfer is Hot air. As the hot air will be in swirling flow, there will be a high friction force of 3.37 and 2.94 times when compared with plain tube, and $\mathrm{y}=5.0$ and 7.0 respectively. Further it is also found that friction will be smaller for $\mathrm{y}=5.0$ and higher for $\mathrm{y}=7.0$. Rectangular and square duct inserted has a twisted tape insert with axial corrugations investigated experimentally by Sujoy Kumar [2] .here the twisted tape has two forms that is tape with and without oblique teeth. The medium used for heat transfer is Hot air, the rages of the Reynolds number will be 10,000 to 100,000 .there is a $50 \%$ better performance in the twisted tube without Tilted teeth when compared with twisted tube with tilted teeth of axial corrugation.

Heat transfer in copper pipe with stainless steel twisted tape has the ratio of 5:3 is investigated in an experiment done by Bodius et al. The Reynolds number range varied from 9500 to 20000 , the smooth tube has heat flux variation from 9 to $18 \mathrm{kw} / \mathrm{m}^{2}$ and 15 to $31 \mathrm{kw} / \mathrm{m}^{2}$ for tube having the twisted tape insert [3]. There is an increase of Nusselt number for the tube having the insertion of twisted tape was about 2.9 to 4 times than that of the smooth tube. The heat flux had increased averagely as $70 \%$ for tube with twisted tape insert than the smooth tube. The investigation of heat transfer with the ratio ranges from 2 to 4 with the intervals of 0.5 and the clearance ratio $(C / D=0.0178$ and 0.0357$)$ with 5132 to 24989 is the range of the Reynolds number is experimented by Halit Bas and Veysel Ozceyhen. It is also tested with zero clearance ratios for comparison [4]. They have also stated that the clearance ratio decreases when the Nusselt number increases. Increases in the twist ratio will also plays vital role in the increase of Reynolds number. They have found that at 1.756 with the clearance ratio of 0.0178 the highest heat transfer rate is obtained.

Center wings and alternate axis in twisted tape investigated for the thermo hydraulic properties by Eiamsa-ard et al. This experiment was conducted with three types of twisted tape, tape with wings alone, tape with alternate axis, typical twisted tape with the twist ratio of 3.0 [5]. 


\section{Influence of Geometry of Twisted Tape Insert on Heat Transfer Augmentation}

The Reynolds numbers conducted ranges between 5200 to 22000. Twisted wings were formed at the middle line of the tape with three varied angles namely 43, 53, and 74. In further it is also found that twisted tape with middle axis and another axis gave the highest performance in the Nusselt number and friction factor and thermal performance with $17.7 \%, 30.6 \%$ and $7.8 \%$ compared with twisted tape with center wings, $20.8 \%, 53 \%$ and 4.9 higher than twisted tape with another axis, $62 \%, 123 \%$ and $24 \%$ higher than the twisted tube

The experimental of visualization of flow characteristic produced by twisted tape having another axis and classic twisted tape was conducted by Panida Seemawute and Smith Eiamsa ard [6]. It is carried out with technique of dye injection, the outcome of the twist ratio for heat transfer and fluid friction are also resolute from this visualization method. The twisted tape with another axis performed better than the typical twisted tape. The experimental investigation of twisted tape with rectangular cut with tube side coefficient of heat transfer was conducted by Bodius Salam et al [7]. They used water as flow median with a Reynolds number ranging from $10000-19000$ and 14 to $22 \mathrm{kw} / \mathrm{m}^{2}$ is the variation of heat flux for even tube and $23-40 \mathrm{kw} / \mathrm{m}^{2}$ for the tube with insert. Nusselt number acquired from twisted tape insert with rectangular cut 2.3 to 2.9 times higher the rate of friction factors from 1.4 to 1.8 times when compares with even tubes. They had found that the coefficient of heat transfer of 1.9 to 2.3 will raised by the raise in Reynolds number.

Flow and Heat transfer has been numerically investigated by Computational Fluid Dynamics Arsha et al [8]. They used circular tubes with twisted tape inserted having the twisted ratio of 3 and 4 considerably along with plain tube for comparison. They conducted the analysis by three Reynolds numbers 8500, 11000 and 14000. Simulations are conducted in the basic Computational Fluid Dynamics tool, ANSYS FLUENT. The changes in the Nusselt number, Heat Transfer and Friction Factor has been reported. The compared variation in the Nusselt number for experimental and Analytical basis are $58-70 \%$ and $65-75 \%$ respectively, for the twist ratio 3.0 and $36-42 \%$ and $36-48 \%$ for the twist ratio 4 .

The experiment of round pipe with central spiral corrugation unevenness, having the twisted tube with tilted teeth is investigated by Pranab Kumar Pal and Sujoy Kumar Saha. The viscous oil is the medium used here with laminar flow. The angle ranges from $0^{\circ}$ to $90^{\circ}$ [9]. The friction factor will have raise in a certain value and Nusselt number respectively. The twist ratio for the tape is 2.5 and 5 with the helix angle will be from $30^{\circ}$ to $60^{\circ}$ with the intervals of $15^{\circ}$ and the height will be of $0.05263,0.07895$ and 0.1053 . From these given terms, the heat transfer is increased by $21-85 \%$ for constant pumping and there is reduction of $64-80 \%$ in pump power. A four-sided duct with winglet vortex generator and the combined twisted tape has experimental study for heat transfer by Pongjet Promvonge et al. The air is the flow median in this experiment with the 4000 to 30000 is the ranges for the Reynolds number [10]. The twisted ratio in the tape is 4 and 5 for the three winglet to the duct, the height ratios ranges from 0.1 to 0.5 with time intervals of 0.5 and the winglet pitch of the tape width ratio are 2, 2.5, 4 and 5. Form these values the experiment is conducted. From this experimental setup, they have founded that there is a $17 \%$ higher performance in heat transfer at the vortex flow than to the plain twist tube insert.

Perforated helical twisted tape is been investigated for heat transfer by Nanan et al [11]. They conducted with various span ratios of 0.2 to 0.6 with an intervals of 0.2 and various perforation pith ratio (s/w) of 1 to 2 with an intervals of $0.5,2$ and 3 were the respective pitch ratio and twist ratio. The Reynolds number ranges from 6000 to 20000. This investigation will be carried out in normal tube and helical twisted tape inserted tube for comparison. Heat transfer, friction loss and thermal performance characters increases because of the span ratio decreases and pitch ratio raises. They had concluded the maximum performance factor as 1.28 by perforated helical twist tube.

Twisted tape inserted in the square duct and the circular pipes were the flow of ethylene glycol will be laminar is experimentally conducted by S.V. Patil and P.V Vijay Babu [12]. The varied twist ratios are $y=2.66,3.55,4.01$ and 5.10. The Reynolds Number ranges from 50 to 1000 . And the flow through four-sided duct and circular tubes with twisted tube are also considered for the comparison of the thermal and friction factors. They concluded that the Nusselt numbers are 5.44 to 7.49 and 2.46 to 4.87 times greater for the plain four-sided duct and for the constant twist ratio is 2.66 and the mean Nusselt number is 2.10 times greater for the given circular tube.

The thermo hydraulic performance of several types of helical twisted tapes had investigated by Smith Eiamsa-ard et al in the method experimentation [13]. The heat transfer augmentation by three types of helical twisted tape with the tape width ratio of 0.1 to 0.2 with intervals of 0.05 for calculating the friction factor, thermal performance and heat transfer. Here the ranges of the Reynolds number from 6000 to 20,000 . There is a raise in the Nusselt number of double helical twisted tube and triple helical twisted tube of $15.6 \%$ to $17.6 \%$ and $19.5 \%$ to $23.4 \%$ respectively. The friction factor is also increased by $83 \%$ to $206 \%$ and $143 \%$ to $335 \%$. And there is an increase of $3.9 \%$ to $20.3 \%$ and $8.3 \%$ to $26.2 \%$ in thermal performance. When related with single helical twisted tubes. The multi shaped duct with twisted tape insert is been investigated for the heat transfer and friction factor by Rupesh J. Yadav et al. They compared the non-circular duct with the circular duct. They used different twisted ratios ( $\mathrm{Y}=3.5,4.5$, 5.5 and 6.5). 400 to 2500 were the ranges of Reynolds number. Finally they had concluded the plain duct with insertion of twisted tape has a raise in Friction Factor and Nusselt number [14].

Tapered twisted tapes with alternate angles has been investigated for heat transfer by the method of experimentation Piriyarungrod et al [15] .The varying twist ratios for the are 3.5 and 4.0 and 4.5. 6000 to 20,000 was the range of the Reynolds Number. They had resolved that the 1.05 is the maximum thermal performance factor is given by tube with twisted tape with angle of $0.9^{\circ}$ and twist ratio, 3.5 at Reynolds number 6000 . Single double and triple twisted tapes inserted in the tube were the heat transfer is numerically investigated by Zhu and Chen with a single phase convective method [16].

\section{Published By:}


They used wall surface improvement equations and second order discrete FVM method to calculate the flow characteristic for air and heat transfer. They compared the results with classical empirical equation. And concluded that the resistance has increased by $6.0-8.7$ with the insertion of single twisted tape, by $9.4-14.4$ with double twisted tape insert and higher value of $13.5-21.2$ with the triple twisted tape in the tube.

The heat transfer has been analyzed in the tube with twisted tape insert in an experiment conducted by Ramakumar et al [17] In the Computational Fluid Analysis the taper increases along the flow direction. They have a fixed twist ratio of 3 . The twist tape angle will vary from 0.3 to 0.7 with the interval of 0.1. Three Reynolds numbers get fixed for the CFD analysis 8545, 11393 and 13333. They calculated the heat transfer pressure drop as Nusselt number and the overall performance ratio was increased by $17 \%$. The overall enhancement ratio is estimated with the taper angle as 0.5 . heat transfer was investigated in a plain circular tube inserted with double twisted tape with $\mathrm{v}$ shaped ribs at an angle of $30^{\circ}$ in an experiment conducted by Sombat Tamna et al [18]. They have used air as a testing fluid with the Reynolds number ranging from 5300 to 24000 . They have the fixed twist ratio as 4 and the four $\mathrm{v}$ shaped ribs called as block ratios are $0.07,0.09,0.14$ and 0.19 . They concluded that the heat transfer and pressure loss were higher in the largest blockage ratio with $\mathrm{v}$ ribbed twisted tapes. The Nusselt number varies from $1.56-2.3$ while the friction force will range from $2.06-$ 4.94 times for the ordinary tube.

The tube is numerically investigated for the heat transfer fitted with twisted tape swirl generators in an experiment conducted by Suvanjan Bhattacharyya et al. [19] They had the configuration parameters entrance angle pitch in the range of $180 *, 160 *$ and $140 *, 100$ to 20,000 was the varying range of the Reynolds number. They had concluded with the result of the larger entrance angle and the smallest twist ratio has increased efficiently because of high turbulence intensity. The heat transfer is investigated in a tube with multiple four-sided perforated twisted tapes with geometrical parameters like width ratio and twist ratio in an experiment conducted by Amar Raj Singh Suri et al. [20]. Here the ratio width varies from 0.083 to 0.333 and twist ratio also various from 2.0 to 3.5 and the Reynolds number varies from 5000 to 27,000 . They had compared the perforated square twist tape with plain twist plate. They had concluded that the Nusselt number is maximum when the ratio of width is 0.250 and the ratio of twist is 2.5 , the friction force is maximum when the ratio of width is 0.250 and ratio of twist is 2.0 and the maximum thermo hydraulic performance occurred at the ratio of width is 0.250 and ratio of twist is 2.5 .

Gawande and A.V Deshmukh had experimented the coefficient of heat transfer in the tube side and circular tube for the friction factor with the twisted tape having rectangular cut with the twist ratio of 5.25[21]. They have compared this with twisted tape with and without elliptical hole. They used air as a median, 10,000 to 19,000 was the variation of the Reynolds number. The increase of Nusselt number is at a rate of 28 to $30 \%$ for the tape without elliptical cut and changes from 47 to $60 \%$ for the tape with elliptical hole in it. They had concluded that the twisted tape with the vent is seen 2 to $4 \%$ efficient than the ordinary tape. The summary of the review is reported in table 1 .

TABLE 1 SuMmery Of THE OBSERVATIONS OF THE STUdy

\begin{tabular}{|c|c|c|c|c|c|}
\hline Reference & Authors & $\begin{array}{c}\text { Type of } \\
\text { Fluid/Reynolds } \\
\text { Number }\end{array}$ & $\begin{array}{l}\text { Configuration of } \\
\text { Twisted Tape }\end{array}$ & Investigation & Observations \\
\hline [1] & Watcharin et al & $\begin{array}{l}\text { Hot Air } \\
2000<\operatorname{Re}<12000\end{array}$ & $\begin{array}{l}\text { Insertion of } \\
\text { twisted tape in } \\
\text { Concentric } \\
\text { double pipe }\end{array}$ & $\begin{array}{l}\text { Investigation of } \\
\text { Twisted tape in } \\
\text { concentric } \\
\text { double pipe }\end{array}$ & $\begin{array}{l}\text { Friction force } \\
3.37 \text { times } \\
\text { higher than the } \\
\text { plain tube for } \\
y=5.0 \text { and } 2.97 \\
\text { times for } y= \\
7.0 \text {. }\end{array}$ \\
\hline [2] & Sujoy kumar & $\begin{array}{l}\text { Hot Air } \\
10,000<\operatorname{Re}<12000\end{array}$ & $\begin{array}{l}\text { Twisted tape } \\
\text { with oblique } \\
\text { teeth }\end{array}$ & $\begin{array}{l}\text { Investigation of } \\
\text { twisted tape } \\
\text { with oblique } \\
\text { teeth in } \\
\text { Non-Circular } \\
\text { Tube } \\
\end{array}$ & $\begin{array}{l}\text { The } \\
\text { performance is } \\
50 \% \text { higher }\end{array}$ \\
\hline [3] & Bodius et al & $\begin{array}{l}\text { Water } \\
9500<\operatorname{Re}<20,000\end{array}$ & $\begin{array}{l}\text { Stainless steel } \\
\text { Twisted Tape }\end{array}$ & $\begin{array}{l}\text { Investigation } \\
\text { stainless twisted } \\
\text { tape in circular } \\
\text { pipe }\end{array}$ & $\begin{array}{l}\text { An average of } \\
70 \% \\
\text { enhancement } \\
\text { is seen in the } \\
\text { heat flex than } \\
\text { the smooth } \\
\text { tube. }\end{array}$ \\
\hline [4] & $\begin{array}{l}\text { Halit bas and } \\
\text { Veysel } \\
\text { Ozceyhen }\end{array}$ & $\begin{array}{l}\text { Air } \\
5132<\operatorname{Re}<24,989\end{array}$ & $\begin{array}{l}\text { Twisted tape } \\
\text { inserted in the } \\
\text { Separation of } \\
\text { Tube Wall }\end{array}$ & $\begin{array}{l}\text { Investigation of } \\
\text { Heat transfer } \\
\text { with the twisted } \\
\text { tape insert }\end{array}$ & $\begin{array}{l}\text { The heat } \\
\text { transfer rate is } \\
\text { higher as } 1.756 \\
\text { for } \mathrm{c} / \mathrm{D}= \\
0.0178 \text {. }\end{array}$ \\
\hline [5] & Eiamsa-ard et al & $\begin{array}{l}\text { Water } \\
5200<\operatorname{Re}<22,000\end{array}$ & $\begin{array}{l}\text { Twisted tape } \\
\text { with centre } \\
\text { wings and } \\
\text { alternate axis }\end{array}$ & $\begin{array}{l}\text { Investigation of } \\
\text { heat transfer of } \\
\text { twisted tape }\end{array}$ & $\begin{array}{l}\text { A higher } \\
\text { Nusselt } \\
\text { number, } \\
\text { friction factor, } \\
\text { and thermal } \\
\text { performance of } \\
62 \%, 123 \% \text { and } \\
24 \% \text { has been } \\
\text { recorded } \\
\text { respectively. }\end{array}$ \\
\hline [6] & $\begin{array}{l}\text { Panida } \\
\text { seemawute and } \\
\text { smith eiamsa } \\
\text { ard }\end{array}$ & $\begin{array}{l}\text { Water } \\
10<\operatorname{Re}<10,000\end{array}$ & $\begin{array}{l}\text { Twisted tape } \\
\text { with alternate } \\
\text { axis }\end{array}$ & $\begin{array}{l}\text { Investigation of } \\
\text { Flow and heat } \\
\text { transfer of } \\
\text { twisted tape } \\
\text { with alternate } \\
\text { axis }\end{array}$ & $\begin{array}{l}\text { Higher Nusselt } \\
\text { number of } 70 \% \\
\text { and friction } \\
\text { factor of } 110 \% \\
\text { for y/W=3 in } \\
\text { the twisted } \\
\text { tape with } \\
\text { alternate axis } \\
\text { is denoted. }\end{array}$ \\
\hline [7] & $\begin{array}{l}\text { Bodius salam et } \\
\text { al }\end{array}$ & $\begin{array}{l}\text { Water } 10,000 \\
<\operatorname{Re}<19,000\end{array}$ & $\begin{array}{l}\text { Twisted tape } \\
\text { with rectangular } \\
\text { cut }\end{array}$ & $\begin{array}{l}\text { Investigation of } \\
\text { heat transfer } \\
\text { with the } \\
\text { rectangular cut } \\
\text { twisted tape }\end{array}$ & $\begin{array}{l}\text { Difference in } \\
\text { Nusselt } \\
\text { number } 2.3 \text { to } \\
2.9 \text { and } \\
\text { Friction factor } \\
\text { is } 1.4 \text { to } 1.8 \text {. }\end{array}$ \\
\hline [8] & Arsha et al & $\begin{array}{l}\text { Air 8500, 11000, } \\
14000\end{array}$ & Twisted tape & $\begin{array}{l}\text { Investigation of } \\
\text { heat transfer in } \\
\text { twisted tape } \\
\text { with CFD }\end{array}$ & $\begin{array}{l}\text { A comparison } \\
\text { done on the } \\
\text { results of the } \\
\text { experimental } \\
\text { and analytical } \\
\text { work for that } \\
\text { the friction } \\
\text { factor } 58-70 \% \\
\text { and Nusselt } \\
\text { number } \\
65-75 \% \text { for TR } \\
3.0\end{array}$ \\
\hline [9] & $\begin{array}{l}\text { Pranab kumar } \\
\text { pal and sujoy } \\
\text { kumar saha }\end{array}$ & $\begin{array}{l}\text { Viscous Oil } \\
1<\operatorname{Re}<1000\end{array}$ & $\begin{array}{l}\text { Twisted tape } \\
\text { with oblique } \\
\text { teeth }\end{array}$ & $\begin{array}{l}\text { Investigation of } \\
\text { circular duct } \\
\text { with integral } \\
\text { spiral } \\
\text { corrugation }\end{array}$ & $\begin{array}{l}\text { For the } \\
\text { corrugation } \\
\text { helix angle } \\
\text { heat transfer } \\
\text { has increased } \\
\text { by } 21-85 \% \text {. }\end{array}$ \\
\hline$[10]$ & $\begin{array}{l}\text { pongjet } \\
\text { promvonge et al }\end{array}$ & $\begin{array}{l}\text { Air } \\
4000<\operatorname{Re}<30,000\end{array}$ & $\begin{array}{l}\text { Twisted tape } \\
\text { with } V \text {-Winglets } \\
\text { on two and four } \\
\text { walls }\end{array}$ & $\begin{array}{l}\text { Investigation of } \\
\text { swirl vortex }\end{array}$ & $\begin{array}{l}\text { Recorded a } \\
17 \% \text { higher } \\
\text { performance of } \\
\text { heat transfer } \\
\text { with vortex } \\
\text { flow. } \\
\end{array}$ \\
\hline [11] & k. Nanan et al & $\begin{array}{l}\text { Water } \\
6000<\operatorname{Re}<20,000\end{array}$ & $\begin{array}{l}\text { Perforated } \\
\text { Helical Twisted } \\
\text { Tape }\end{array}$ & $\begin{array}{l}\text { Investigation of } \\
\text { heat transfer } \\
\text { with perforated } \\
\text { helical twisted } \\
\text { tape }\end{array}$ & $\begin{array}{l}\text { The maximum } \\
\text { performance } \\
\text { factor is } \\
\text { observed as } \\
1.28 \text { in } \\
\text { perforated } \\
\text { helical twisted } \\
\text { tape. }\end{array}$ \\
\hline [12] & $\begin{array}{l}\text { S.v. patil and } \\
\text { P.v vijay babu }\end{array}$ & $\begin{array}{l}\text { Ethylene glycol } \\
50<\operatorname{Re}<1000\end{array}$ & Twisted tape & $\begin{array}{l}\text { Investigation of } \\
\text { heat transfer in } \\
\text { square duct } \\
\text { inserted with } \\
\text { twisted tape }\end{array}$ & $\begin{array}{l}\text { Observed a } \\
2.10 \text { times } \\
\text { greater Nusselt } \\
\text { number for the } \\
\text { square duct } \\
\text { insertion. }\end{array}$ \\
\hline
\end{tabular}




\begin{tabular}{|c|c|c|c|c|c|}
\hline$[13]$ & $\begin{array}{l}\text { Smith eiamsa } \\
\text {-ard et al }\end{array}$ & $\begin{array}{l}\text { Air } \\
6000<\operatorname{Re}<20,000\end{array}$ & $\begin{array}{l}\text { Helical Twisted } \\
\text { Tape }\end{array}$ & $\begin{array}{l}\text { Investigation of } \\
\text { thermohydrauli } \\
\text { c performance } \\
\text { with double and } \\
\text { triple helical } \\
\text { twisted tape }\end{array}$ & 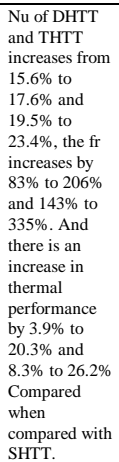 \\
\hline$[14]$ & $\begin{array}{l}\text { Rupesh J. } \\
\text { Yadav et al }\end{array}$ & Air $400<\operatorname{Re}<2500$ & $\begin{array}{l}\text { Twisted tape } \\
\text { with different } \\
\text { Twist Ratio }\end{array}$ & $\begin{array}{l}\text { Investigation of } \\
\text { friction factor } \\
\text { and heat } \\
\text { transfer in } \\
\text { non-circular } \\
\text { tubes }\end{array}$ & $\begin{array}{l}\text { The Nusselt } \\
\text { Number ras } \\
\text { increased from } \\
7 \text { to } 1 \text { land the } \\
\text { friction factor } \\
\text { increased from } \\
0.65 \text { to } 0.8 \text { for } \\
\text { the Re } 2500 \text {. }\end{array}$ \\
\hline$[15]$ & $\begin{array}{l}\mathrm{N} \text {. } \\
\text { Piriyarungrod et } \\
\text { al }\end{array}$ & $\begin{array}{l}\text { Water } \\
6000<\operatorname{Re}<20,000\end{array}$ & $\begin{array}{l}\text { Tapered Twisted } \\
\text { Tape }\end{array}$ & $\begin{array}{l}\text { Investigation of } \\
\text { heat transfer } \\
\text { with Tapered } \\
\text { twisted tape } \\
\text { insert }\end{array}$ & $\begin{array}{l}\text { Recorded a } \\
\text { maximum } \\
\text { thermal } \\
\text { performance } \\
\text { factor of } 1.05 \\
\text { for the taper } \\
\text { angle of } 0.9^{*} \\
\text { and the Tr is } \\
3.0 .\end{array}$ \\
\hline$[16]$ & $\begin{array}{l}\text { J.D Zhu and } \mathrm{H} \text {. } \\
\text { Chen }\end{array}$ & Water $R e=20,000$ & $\begin{array}{l}\text { Double spiral } \\
\text { and triple spiral } \\
\text { Twisted tape }\end{array}$ & $\begin{array}{l}\text { Investigation of } \\
\text { numerical study } \\
\text { o enhanced heat } \\
\text { transfer }\end{array}$ & $\begin{array}{l}\text { Observed an } \\
\text { increase in the } \\
\text { Resistance } \\
\text { from } 6.0-8.7 \\
\text { for single TTI } \\
\text { and } 9.4-14.4 \\
\text { for double TTI } \\
\text { and } 13.5-21.2 \\
\text { with hhe triple } \\
\text { TTI. }\end{array}$ \\
\hline$[17]$ & $\begin{array}{l}\text { B.V.N } \\
\text { Ramakumar et } \\
\text { al }\end{array}$ & $\begin{array}{l}\text { Water Re=8545, } \\
11393 \text { and } 13333\end{array}$ & $\begin{array}{l}\text { Tapered Twisted } \\
\text { Tapes }\end{array}$ & $\begin{array}{l}\text { Investigation of } \\
\text { numerical } \\
\text { analysis with } \\
\text { tapered twisted } \\
\text { tape }\end{array}$ & $\begin{array}{l}\text { Recorded an } \\
\text { increase in the } \\
\text { overall } \\
\text { performance } \\
\text { as } 17 \% \text { in the } \\
\text { taper angle } \\
0.5\end{array}$ \\
\hline$[18]$ & $\begin{array}{l}\text { Sombat Tamna } \\
\text { et al }\end{array}$ & $\begin{array}{l}\text { Air } \\
5300<\operatorname{Re}<24,000\end{array}$ & $\begin{array}{l}\text { V- Ribbed } \\
\text { Twisted Tapes }\end{array}$ & $\begin{array}{l}\text { Investigation Of } \\
\text { heat transfer in } \\
\text { tubular heat } \\
\text { exchanger with } \\
\text { v ribbed twisted } \\
\text { tapes }\end{array}$ & $\begin{array}{l}\text { Observed an } \\
\text { increase in the } \\
\text { Nusselt } \\
\text { Number from } \\
1.56-2.3 \\
\text { times and the } \\
\text { Friction Factor } \\
\text { from } 2.06- \\
4.94\end{array}$ \\
\hline [19] & $\begin{array}{l}\text { Suvanjan } \\
\text { Bhattacharyya } \\
\text { et al }\end{array}$ & $\begin{array}{l}\begin{array}{l}\text { Air } \\
100<\operatorname{Re}<20,000\end{array}\end{array}$ & $\begin{array}{l}\text { Twisted tape } \\
\text { turbulator }\end{array}$ & $\begin{array}{l}\text { Investigation of } \\
\text { heat transffer } \\
\text { with twisted } \\
\text { tape turbulator } \\
\text { at difference } \\
\text { entrance angle }\end{array}$ & $\begin{array}{l}\text { Recorded that } \\
\text { the largest } \\
\text { entrance angle } \\
\text { and the } \\
\text { smallest } \\
\text { twisted ratio } \\
\text { will increase } \\
\text { with the high } \\
\text { turbulence } \\
\text { intensity. }\end{array}$ \\
\hline [20] & $\begin{array}{l}\text { Amar Raj Singh } \\
\text { Suri et al }\end{array}$ & $\begin{array}{l}\text { Water } \\
5000<\operatorname{Re}<27000\end{array}$ & $\begin{array}{l}\text { Multiple square } \\
\text { perforated } \\
\text { twisted tape }\end{array}$ & $\begin{array}{l}\text { Investigation of } \\
\text { heat transfer in } \\
\text { the multiple } \\
\text { square } \\
\text { perforated } \\
\text { twisted tape }\end{array}$ & $\begin{array}{l}\text { Observed the } \\
\text { maximum } \\
\text { thermo } \\
\text { hydraulic } \\
\text { performance at } \\
\text { a width ratio of } \\
0.25 \text { and the } \\
\text { twistratio } 25\end{array}$ \\
\hline [21] & $\begin{array}{l}\text { K.R. Gawande } \\
\text { and A.V } \\
\text { Deshmmkh }\end{array}$ & $\begin{array}{l}\text { Air } \\
10,000<\operatorname{Re}<19000\end{array}$ & $\begin{array}{l}\text { Twisted tape } \\
\text { with and without } \\
\text { elliptical hole }\end{array}$ & $\begin{array}{l}\text { Investigation of } \\
\text { tube side heat } \\
\text { transfer rate } \\
\text { with elliptical } \\
\text { hole }\end{array}$ & $\begin{array}{l}\text { Observed that } \\
\text { the Nusselt } \\
\text { number has } \\
\text { increased from } \\
28-38 \% \\
\text { without the } \\
\text { elliptical hole } \\
\text { and from } \\
47-60 \% \text { with } \\
\text { hole. }\end{array}$ \\
\hline
\end{tabular}

\section{CONCLUSION}

This review reports that the heat transfer through the heat exchangers raised by changing the characteristics in the flow passage of the fluids by introducing inserts. Based on the surface contact of the fluids with the inserts the heat transfer noticeably increased. This review depicts influence of the geometry of the twisted tapes making swirl passages and tapes with different dimensions shows a higher heat transfer coefficient. It increased with twisted tape with different dimensions like having rectangular cut, oblique teeth, helical twisted tape; V- ribbed twisted tapes and elliptical hole on the twisted tapes. Many of the researches reported the change in twist ratio leads to get accurate twist ratio at which the maximum heat transfer rate acquired. Still there exists a scope for the further research in this influence of twisted tapes considering in transverse direction of flow instead of axial flow situations.

\section{REFERENCES}

[1] W. Noothong, S. Eiamsa-ard, and P. Promvonge., "Effect of Twisted-tape Inserts on Heat Transfer in a Tube" 2nd Jt. Int. Conf. Sustain. Energy Environ., vol. 30, no. 2, 2006 pp. 19-23.

[2] S. K. Saha., "Thermohydraulics of turbulent flow through rectangular and square ducts with axial corrugation roughness and twisted-tapes with and without oblique teeth" Exp. Therm. Fluid Sci., vol. 34, no. 6 , 2010 pp. 744-752.

[3] B. Salam., "Heat transfer enhancement in a tube using twisted tape insert," Proc. 13th Asian Congr. Fluid Mech., vol. 2, no. 5, 2010 pp. 20-27.

[4] H. Bas and V. Ozceyhan., "Heat transfer enhancement in a tube with twisted tape inserts placed separately from the tube wall" Exp. Therm. Fluid Sci., vol. 41, 2012 pp. 51-58.

[5] S. Eiamsa-ard, K. Wongcharee, P. Eiamsa-ard, and C. Thianpong., "Thermohydraulic investigation of turbulent flow through a round tube equipped with twisted tapes consisting of centre wings and alternate-axes" Exp. Therm. Fluid Sci., vol. 34, no. 8, 2010 pp. $1151-1161$.

[6] P. Seemawute and S. Eiamsa-ard.,. "Simulation of Flow and Heat Transfer in Tube with Twisted Tape Consisting of Alternate Axis" 4th Int. Conf. Comput. Model. Simul., vol. 22, no. Iccms,2012 pp. 36-40.

[7] B. Salam, S. Biswas, S. Saha, and M. M. K. Bhuiya., 2013. "Heat transfer enhancement in a tube using rectangular-cut twisted tape insert" Procedia Eng., vol. 56, 2013 pp. 96-103.

[8] J. D. Arsha, B. V. N. Ramakumar, P. Tayal, and K. Padmanabhan., "Numerical investigations on flow and heat transfer characteristics of a tube equipped with twisted tape inserts" 2013 Int. Conf. Energy Effic. Technol. Sustain. ICEETS 2013, pp. 101-107.

[9] S. Pal and S. K. Saha "Experimental investigation of laminar flow of viscous oil through a circular tube having integral axial corrugation roughness and fitted with twisted tapes with oblique teeth" Heat Mas. Transf. und Stoffuebertragung, vol. 51, no. 8, 2015 pp. 1189-1201.

[10] P. Promvonge, S. Suwannapan, M. Pimsarn, and C. Thianpong., "Experimental study on heat transfer in square duct with combined twisted-tape and winglet vortex generators" Int. Commun. Heat Mass Transf., vol. 59, 2014 pp. 158-165.

[11] K. Nanan, C. Thianpong, P. Promvonge, and S. Eiamsa-ard., "Investigation of heat transfer enhancement by perforated helical twisted-tapes" Int. Commun. Heat Mass Transf., vol. 52, 2014 pp. 106-112.

[12] S. V. Patil and P. V. Vijay Babu., "Laminar heat transfer augmentation through a square duct and circular tube fitted with twisted tapes" Exp. Heat Transf., vol. 27, no. 2,2014 pp. 124-143.

[13] S. Eiamsa-Ard, K. Nanan, K. Wongcharee, K. Yongsiri, and C. Thianpong., "Thermohydraulic Performance of Heat Exchanger Tube Equipped with Single-, Double-, and Triple-Helical Twisted Tapes" Chem. Eng. Commun., vol. 202, no. 5, 2015 pp. 606-615.

[14] R. J. Yadav, S. Kore, V. N. Raibhole, and P. S. Joshi., "Development of Correlations for Friction Factor and Heat Transfer Coefficient for Square and Hex Duct with Twisted Tape Insert in Laminar Flow" Procedia Eng., vol. 127, 2015 pp. 250-257.

[15] N. Piriyarungrod, S. Eiamsa-ard, C. Thianpong, M. Pimsarn, and K Nanan., "Heat transfer enhancement by tapered twisted tape inserts" Chem. Eng. Process. Process Intensif., vol. 96, 2015 pp. 62-71.

[16] J. D. Zhu and H. Chen., "Numerical Study on Enhanced Heat Transfer by Twisted Tape Inserts inside Tubes" Procedia Eng., vol. 130, 2015 pp. 256-262.

[17] B. V. N. Ramakumar, J. D. Arsha, and P. Tayal., " Tapered Twisted Tape Inserts for Enhanced Heat Transfer” J. Heat Transfer, vol. 138, no. 1,2015 p. 11901.

[18] S. Tamna, Y. Kaewkohkiat, S. Skullong, and P. Promvonge "Heat transfer enhancement in tubular heat exchanger with double V-ribbed twisted-tapes" Case 
[19] S. Bhattacharyya, H. Chattopadhyay, and A. Haldar., "Design of twisted tape turbulator at different entrance angle for heat transfer enhancement in a solar heater" Beni-Suef Univ. J. Basic Appl. Sci. 2018 pp.118-126.

[20] A. R. S. Suri, A. Kumar, and R. Maithani., "Experimental determination of enhancement of heat transfer in a multiple square perforated twisted tape inserts heat exchanger tube" Exp. Heat Transf., vol. 31, no. 2, 2018 pp. 85-105.

[21] K. R. Gawande and A. V Deshmukh., " Experimental Investigation of Heat Transfer Rate Using Twisted Tape with Elliptical Holes" Int. Conf. Sci. \& Engg. For Sustainable Devlopment no. May 2017 pp. $105-112$.

\section{AUTHORS PROFILE}

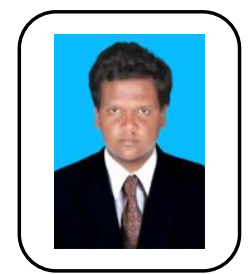

S. Sam Godwin Sathyaraj is a Research Scholar at Department of Automobile Engineering in Kalasalingam Academy of Research and Education, Krishnankoil. He holds Master of Engineering (Engineering Design) from SVS College of Engineering, Coimbatore and Bachelor of Engineering (Mechanical) from Kalasalingam University, Krishnankoil.

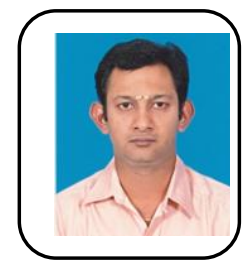

Jaganathan. K.D obtained his Bachelor's Degree in 1999 from Madurai Kamaraj University. Further completed his Master's degree in Computer Integrated Manufacturing from Visvesvaraya Technological University, Belagavi, India in 2001. His research interest includes fluid dynamics, experimental heat transfer and flow separation using CFD techniques. Currently working on the above said research area and published an international journal and communicated three international journals. He started his career as teaching faculty from 2004 and currently working as Assistant Professor in the Department of Mechanical Engineering, SACS MAVMM Engineering College, Kidaripatti, Madurai, India. He holds life membership in Indian Society for Technical Education (ISTE), India.

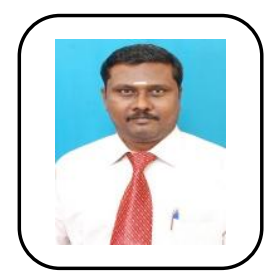

Sivasubramanian. M obtained his Bachelor's Degree in 1999 from Madurai Kamaraj University. Further he completed his Master's degree in Production Engineering from Anna University, India in 2005. He was awarded with Ph.D. degree in Faculty of Mechanical Engineering in the year 2015. During his research career he has published 14 International journals and participated and published many International conferences papers. He actively involved in inventing things related to automobile and mechanical engineering and as an outcome of this, he has registered 19 patents in INDIA. One of his inventions is eco-friendly hybrid electric car with self-electrical charging for which he received a fund of One lakh Rupees from Innovation and Entrepreneurship Development Centre, National Science \& Technology Entrepreneurship Development Board (NSTEDB) Department of Science \& Technology Department of Science and Technology. His research interest includes fluid dynamics, conjugate heat transfer, experimental heat transfer and flow separation using CFD techniques. He started his career as teaching faculty from 1999 and currently working as an Associate Professor in the Department of Automobile Engineering, Kalasalingam Academy of Research and Education, India. He holds life membership in Life member in Indian Society for Heat and Mass Transfer (ISHMT), India and Life member in Indian Society for Technical Education (ISTE), India. 